\title{
Iconography of Yoruba Indigenous Proverbs for Sustainable art Practices
}

\author{
Makinde David Olajide \\ Department of Fine and Applied Arts, Obafemi Awolowo University Ile-Ife
}

\begin{abstract}
The paper highlights the use of proverbial expressions on the socio-cultural and educational developments of the Yoruba people of south western Nigeria prior to the introduction of western education into the land. The paper argued that globalization, westernization, preference for foreign language and the compulsory use of English as a medium of expression in the school curriculum devastatingly and endangered the indigenous culture among the people. The study employed iconography and visualization techniques to process sixteen out of thirty-six purposively selected English translated Yoruba proverbs that were presented. These proverbs were processed into recognizable icons and imageries that were used as motifs for art practices. The paper therefore concludes that iconizing the Yoruba indigenous proverbs for art practices is required to resuscitate and sustain the Yoruba cultural heritage.
\end{abstract}

Keywords:- iconography, Proverbs, Extinction, Culture, Symbolic, Analysis and Art Practice

\section{INTRODUCTION}

The Yoruba people who lived in the Southwestern part of Nigeria are renowned for their rich cultural heritage which survived until the advent of colonization (Bascom, 1969). Like the Akan people of Ghana and Dogon of Mali, the Yoruba people are famous in their use of proverbs to attend to all life situations; hunger, love, hatred, pleasure among other things (Makinde, 2014). Likewise, their use of proverbs in traditional art practices was recorded by scholars who were: Thompson, (1989), Bascom, (1989), Fagg, (1982) among others. Existing studies like those (Salawudeen, 2014), and Paczolay (1996) on the nature of Yoruba proverbs revealed that; proverbs are multi-faceted and contextual because they offer interpretations to different things at different times). Prior to the introduction of western civilization, Yoruba proverbs have been used in different fora to preserve the indigenous ways of life which is now becoming a moribund civilization (Palmer, 1999). Explicating the above, four key informants Ajao, Orilowo, Adigun and Efuntomi, from the study area, attest to the social, spiritual, religious and educational values of Yoruba proverbs to the society. According to the informants, anyone who dexteriously uses proverbs in any conversation is often regarded as super literate and intelligent among the Yoruba people.

Recent studies by Fabunmi, et al (2005), Adegbite, (1988) and Asiyanbola, (2007) have established the facts that; Yoruba proverb within the wealth of language is fast loosing its flavor and acceptability due to proper documentation, in visual art forms that can arouse the interest of the younger generation. Some members of the society also note erroneous believe that; ability to speak and write English language is a standard by which a society is adjudged as being progressive.

Contesting the views above, an informant (Ogunlowo) contends that; many Yoruba people at home, and in the diasporas, became famous because of their ability to speak Yoruba language fluently and creatively. He adds that many became famous through their dexterous and extensive uses of Yoruba proverbs in most of their literary works and not necessarily because of their command of English language. Such people include: Lere Paimo, a foremost indigenous Yoruba theatre icon, Yemi Elebu-Ibon, an Ifa priest and advocate of restoration of Yoruba indigenous language; Wande Abimbola, a professor of Yoruba language, a philosopher, an Ifa priest and award winner of culture ambassador in Nigeria, Akinwumi Isola a University Don, renowned linguists, and dramatists of note, Wole Soyinka, professor and Nobel Lauret among others. Corroborating the view of Ogunwale, (2008), Agbaje, (2005) asserts that; proverb is an important component of Yoruba language which every Yoruba language speaker use to drive home their points during conversation. Contrarily, the selection of Yoruba language as a school subject even for Yoruba candidates in Nigerian schools has been made optional.

Yankah, K (2012) describes proverbs in Africa as succinct familiar sayings of folk wisdom usually compressed in form and frequently involving jingles that catch attention. Similarly, Paul, D (2004) defines it as short term frame of reference on the moral epitome of the peoples experience and expressions on concepts such as ethics, religion, politics, gender issues, natural and physical phenomena, interpersonal relationships, war and peace, jurisprudence, cultural artifacts among others. Discussing further the importance of proverbs among the 
Yoruba, he mentions that it is not very difficult to find any human situation; agony, sorrow, joy, distress, that at least a Yoruba proverb would not be able to capture.

Confirming the sensitivity of Yoruba proverbs, Fabunmi, et al, (2005) observe that the Yoruba people use proverbs in public gatherings to communicate special messages. Notably, they do this with caution to avoid careless, casual, or thoughtless statements whose damage might outlast lifetimes because proverb carries great psychic properties. Arising from the above circumstances the Yoruba people appropriate proverbs to specific situations especially when matters arising become expediently difficult to describe or explicate. This explains why the popular proverb "Òwelẹsin ọrọ̀; bi òrọ̀-ọ básonù, òwe la fi ńwá a (Proverb is the horse of speech; when speech is lost, proverb is the means we use to hunt for it) is opposite and in constant use among the people.

Scholarly work on Yoruba proverbs including Ojo 2006: Fasiku 2006; Ajibade 2006; Adeyemi etal 2009; Ogunwale 2012; Aderinto 2014), confirm the multi-faceted nature of Yoruba proverbs which are found within the contexts of various disciplines like psychology, linguistics, education, and ethnography among others. Evaluating the views of these authors, the author finds that the studies center mainly on uses and relevance of proverbs to the people without focusing on the artistic and iconographic interpretations were not mentioned in these studies. Ojo (2006) and Toni (2013) tersely discussed the artistic and educational values of Yoruba folklores and proverbs in their works these are considered relevant to this study. These studies conclude that language lost may lead to culture lost or culture extinct among the people. The focus of the present paper therefore is to investigate what the Yoruba indigenous iconography could contribute to the overall socio-cultural heritage of the nation..

Diran, (2012), Salawu, (2014), and Adeyemi, etal (2014) established the educational and socio-cultural values of Yoruba proverbs and posited that they have the potentialities to promote visual literacy by interpreting and creating traditional symbols/icons that will creatively explain their meanings. Specifically, the Yoruba proverb 'Eyin lòrò; Bó bá ti balẹ, fifọ́ nií fọ́ (speech is like an egg; when it drops on the floor it shatters) bears witness to delicacy of words which is depicted by the icon of an egg. Likewise, a Yoruba popular proverb which says " òrò níyo obì lápó béèni òrò ní yo idà nínú àkò" (correct and crafty presentation of speech in a situation cause the kola nut to emerge from the pocket, whereas its careless use could call out the sword from its scabbard) further confirms the values of proverbs among the people. The views of these scholars confirm the need to use creative symbols/icons to interpret Yoruba proverbs for art practices which is the focus of this paper The above also suggests that, resort to proverbs in a life situation is the most important and most effective strategy that the Yoruba people have devised to optimize the pragmatic values of their speeches.

Looking at the nature of proverbs, Agbaje (2002) submits that proverbs are often incisive in their propositions and terse in their formulation. He goes further to explain that: proverbs are deduced from close observations with life, life forms, their characteristics, habits of creatures, the environment, natural phenomena, and sober reflections, fauna and flora among others. According to him; they are held to express unspeakable truths, though with some qualifications. Their use in a discussion or argument is tantamount to appeal to established and incontrovertible authority. Perhaps this may be one reason for their virtual indispensability in formal and informal verbal interactions in Yoruba society. They accordingly pervade all other (major) forms of verbal texts, in which their presence enhances the effectiveness of those texts.

Similarly, Mbagu (2014) reviews the significance, similarities and global relevance of proverbs in Africa and beyond and carries out with the view that proverb is a global phenomenon used to express different feelings and situations which are similar in content and context. According to him, the sayings of Africans are some of the most profound words that one will ever hear. Justifying this, Mbagu cited the famous Tanzanian proverb which says "many hands make light work". This is a saying turned proverb that is being adopted all over the world that encourages team work and concerted efforts. He also cited yet another famous proverb from Nigeria which says "it takes a village to raise a child". These two proverbs though structurally different but they corroborated the views of Mbagu as stated above. He concludes that the ways in which proverbs vary from people to people demonstrates the differences, similarities and relevance to cultures, even though they show how very similar people really are universality and and peculiarity are clearly demonstrated in varying degrees and dept.. A Malay proverb 'give him your foot he would demand for your thigh' as similar to the British proverb "Give him an inch he would take a mile" confirms this.

Drawing examples across Africa, Agbaje (2005) explains that; proverbs share with the world practical wisdom that people have learned in their way of life. He also established a relationship between the Zulu proverb which says 'You cannot chase two antelopes at once' as similar to the Yoruba proverb 'Akii le eku meji, ki a ma pa ofo (one cannot chase two rats at the same time without losing them or A ko le ma je isu, ki a tun maa sufe (one cannot be eating Yam and be whistling at the same time). This proverb were developed when Yoruba people found out that they could only capture one animal at a time because if they tried to focus on more than one, the animal they hunt would escape. This practical wisdom of tracking one thing at a time applies to people all over the world, and not just those chasing wildlife. More importantly, proverbs also provide an understanding of the way of life in Africa. The view on gender roles in Africa is also expresses by a proverb 
from Ghana that says 'a woman is a flower in a garden; her husband is the fence around it' (Kquofi, 2013). Proverbs also help to dispel the erroneous belief that a people are barbaric and uneducated the paradigm of their being able to speak in English as a measure of elitism and in that token, they debase whoever cannot. The end result is that they view African lore and proverbs as being irrelevant to out contemporary socio-cultural lives. It need not be repeated here that this is practically not so.

\section{THE STUDY}

In this study, sixteen randomly selected Yoruba proverbs were processed into icon/s for use in art practices. This study therefore provides socio-cultural and symbolic meanings of the sixteen randomly selected Yoruba proverbs while the researcher made iconographical analysis of the icons generated from the proverbs. It provides information on the use of icons as motifs for art practices and the essence of art pedigree.

According to Kylie, (2011) 'Art Practice' refers to both the conceptual and the process of making an art work. According to him, an artwork is a visual representation of idea, design, thoughts and messages expressed in three or two dimensional forms (textiles, graphics, sculptures, paintings, and ceramics). Corroborating the views of Kylie; the study of Graeme (2006) and Geoffrey (2006) agreed that; Art Practice refers to all the things that might be important in the production of an artwork including: treatment and use of materials; representation of thoughts, feelings and experiences; stylistic innovations; the artists intention and philosophy; emerging technologies; personal symbols and signs; ideas and concepts. Therefore, every artwork requires ideas, concept, symbols/icons, technology/skills and adequate materials to be functional and meaningful in the society.

Arising from the above, this study supports the Yoruba proverb which says "Òwe lẹsin ọrọ̣; bi ọ òọ-ọ bá sonù, òwe la fi ńwá a" (Proverb is the horse of speech; when speech is lost, proverb is the means we use to hunt for it). Therefore, this study randomly selected sixteen out of thirty-six purposively selected English translated Yoruba proverbs and iconize them for Art practices with a view to sustaining Yoruba cultural values.

\section{DATA COLLECTION AND PRESENTATION}

The study was carried out in three Yoruba towns (Ede, Ilorin and Oyo) where Yoruba language is widely spoken. Meanings, uses and context of sixteen English translated Yoruba proverbs were investigated through thirty-three native speakers of the language (informants) that consists of five Ifa priests, four herbalists, three academic scholars, six farmers and five traditional dyers and ten ayò game players using structured oral interview technique. Other materials used in this study were sourced from print, electronic media and through direct observations of how proverbs are being used in the study areas. The study adopts descriptive and formal analysis method of art within the context historical research to explicate the contextual, symbolic, socio-cultural and educational relevance of these proverbs to the society. Based on the information gathered, sixteen Yoruba proverbs were processed into icons/imageries using iconographic and visualization techniques.

Iconography is defined in this study as the study of symbolic discourse that consists of texts and images, interpretive principles that people use to make sense in their symbolic representations. Similarly, Panosky, (1984) explains that; there are many other ways to relate a work to history, though, involving different elements of the period from which it came. One of them is an iconographic analysis, which establishes the meaning a work of art had at the time it was made. This may or may not include what the maker of the work intended or, usually a more important factor, what the person who paid for the work wanted. Any particular time or place provides different possible audiences, each of which will demand specific kinds of information and make certain assumptions. In this study, the icon that represents each of the proverbs is both contextual and symbolic in meaning while the Iconographic imageries provide material for art practices.

The use of icons and symbols in Yoruba art is not a recent invention rather, it is an age long tradition that manifests in their art forms which includes; shrine paintings, dyed fabrics, and wood and calabash carvings among others. This randomly selected sixteen (16) out of thirty-six (36) purposively selected English translated Yoruba proverbs that were investigated on the field. This is based on the standard variety of the language because it is the variety that is adopted for Yoruba scholarship while conceptualization and visualization techniques were used to process our data into icons taken from the sixteen selected proverbs configured into visual imageries and symbols. Conceptualization in this study is a process of transforming fluid or raw idea/s in the mind of the artist/author that is developed into visual imageries as used in the study. The author, imagined, developed and created idea or concept of each proverb in the mind by making several sketches (drawing) through visualization before choosing the technique which is most appropriate that will represent each of the proverb in visual form. Visualization in this study refers to a design concept that is developed and used by visual artists to transform texts, speeches, stories or folklores in visual form. This is achieved by reducing an idea expressed in the proverb into simple drawings by making several sketches (drawings) that depict the idea postulated which is the focus of this study. 


\section{IV. $\quad$ FINDINGS}

The study found that indigenous Yoruba proverbs are rich and full of wisdom which need to be visually represented (iconize) and used as a tool for art practices and in the promotion of visual literacy. To achieve this feat, the study selected sixteen (16) English translated Yoruba proverbs. The study iconises, represents and transforms the selected proverbs into sixteen visual imageries in the following order: Yoruba proverbs, English translated Contextual meanings, Socio-cultural relevance, Icons and iconographic analysis. These are presented below.

1. Yoruba Proverbs: Eni tí a rò wi pé kò lè pàgọ́, ó șe bi eré bi eré, ó kọlé aláruru.

English Translated: Someone who has been looked down upon as not being capable to put up a tent later turned out to build a palace residence.

Contextual meaning: The proverb is used when certain individual is utterly demeaned but he eventually emerged gloriously to the amazement of his distractors. A good example is former Nigeria Military Head of State (Olusegun Obasanjo) who came out of prison to become a democratically elected president in 1999. Likewise, former (late) South Africa President, Nelson Mandela came out of prison to become a democratically elected president in 1994.

Socio-Cultural relevance: The proverb is often used to counsel, warn or advice anyone who mocks, underrates or talks ill of other people on the basis of their present situations. The proverb teaches us not to lose hope in whatever situation we may find ourselves.

Icons: Grass-roofed and palatial storey building. (Fig.1)

Iconographic Analysis: The main features in this proverb are Àgó (hut) and Ilé-Aláruru (palatial building). Àgó is used here to represent a small crude shelter used as dwelling place by the poor while ilé-Aláruru (palatial building) in the imagery stands for the affluent in the society. The grass-roofed icon symbolizes poverty while the magnificent storey building stands for wealth and affluence.

2. Yoruba Proverbs: Òị̀à bi ìyá kò sí, ta ló jẹ șe ọmo olọmo lóore.

English Translation: There is no deity like that of motherhood; who dares to be so benevolent and generous as to favour other people's in preference of his/her children.

Contextual meaning: No matter the situation or condition, mothers are like gods that should be worshipped considering their roles in nursing and nurturing of a child.

Socio-Cultural relevance: Orișà (mother) is likened to the gods in whose service peace, love, security, wealth is guaranteed. This proverb underscores the indispensability of motherhood in the context of possession and ownership of the child.

Icon: A nursing mother with a suckling baby (Fig. 2)

Iconographic Analysis: The female figure and the suckling baby are the main icon used in this proverb. The female figure depicts women as source of procreation and life while the suckling baby demonstrates dependency, reliability, life, love, food, good health and shelter which are the basic necessity of life. When a child sucks her mother's breasts, the child feels satisfied and remembers no one.

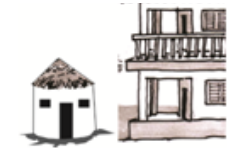

Fig. 1: Eni tí a rò wí pé kò lè pàgọo, ó șe bi eré bi eré ó kọ́lé aláruru

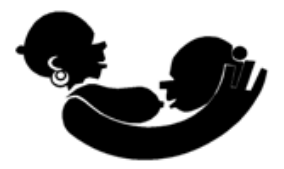

Fig. 2: Ò̀ị̀à bí ìá kò sí, ta ló jệ ṣe ọmọ ọlộmọ

lóore

Yoruba Proverbs: Bí okọ bá ròkun, tó

English Translation: However far travelled a ship, it will eventually end in a harbor

Contextual meaning: There used to be limits to any human activities and upheavals; with accompanying accountability.

Socio-Cultural relevance; This proverb is used as warning for the greed and selfish individuals who cares less about limitations. Most especially, the politicians after securing peoples votes often abandon the electorate to pick new friends but, however make dramatic U-turn at the expiration of their tenure of office.

Icons: Canoe at harbor. (Fig, 3)

Iconographic Analysis: The canoe anchored at the harbor is the main idea from the proverb. The canoe as a device that is used for fishing and transportation in many riverine areas illustrates desperate human struggle that 
takes him up and down. However, after a fruitful or futile journey the canoe returns to harbor for anchorage. This is to say that whatever goes up must definitely come down and that people should always remember their pedigree.

4. Yoruba Proverbs: Ònà ló jìn, ẹrú náà ní baba.

English Translation: However far away, a slave has his own paternity.

Contextual meaning: The proverb is used in the case of undue maltreatment with impunity to educate the perpetrator; that every individual deserves some decorum of dignity because there is no individual without provenance.

Socio-Cultural relevance: This proverb functions mostly as a caution for the brutes or oppressors who often exploit the physical, political, racial or economic weaknesses of the oppressed.

Icons: A slave on a long windy road to his native land. (Fig.4)

Iconographic Analysis: The male figure here represents the slave while the road represents his years of labour and journey to his freedom which confirms that every man has his root however obscure or distant

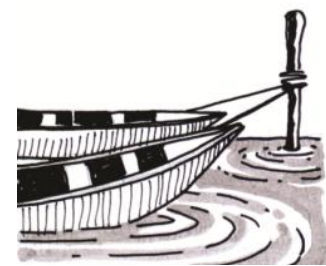

Fig. 3: Bí ọkọ̀ bá ròkun, tó rọ̀sà; a fi orí fún èbúté.

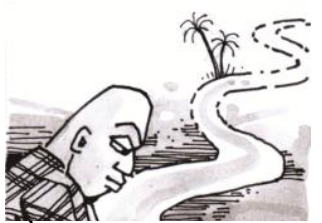

Fig. 4: Ộà ló jìn, ẹrú náà ní baba

5 Yoruba Proverbs: Kìrà-kità kò mọ́là wá, ká șiṣẹ bi ẹrú kò dá nnkan kan fún ni.

English Translation: Strenous labour efforts do not amount to glorious success. Working like a slave is of worthless value.

Contextual meaning: Success is often not determined by the amount of desperate efforts that we make. This proverb is used when a man is seen to be too desperate in achieving a goal in life. Slowly and steady wins the race, according to another English proverb.

Socio-Cultural relevance: This explains a situation where an individual is chasing after something that is above his/her income or beyond his reach. For instance, when a man engages himself in so many incongruent businesses without rest and it turns out not translating to making money

Icon: A traditional carver at work. (Fig.5)

Iconographic Analysis: A traditional carving process is arduous and requires utmost concentration, energy and strength. Naturally, these factors are also required to succeed in life. Sometimes, the physical energy and time expended on a project may not usually be commensurate with the level of success achieved.

6. Yoruba Proverbs: Eni tó tafà sókè tó yídó borí, bi oba ayé kò ri í, tọrun ń wò o.

English Translation: One who hides under a mortar to shoot an arrow should know that even when no one sees him, his deed is openly revealed to the gods

Contextual meaning: The proverb is used when it is erroneously assumed that the evil that has been perpetrated is hidden and not known to any living being whereas nothing is hidden to God almighty

Socio-Cultural relevance: In traditional African society, bowl and arrows are not used for child's play; rather, they are instrument of war. The shooter of the arrow is depicted to have disguised himself from the impact of his arrow by hiding himself under the mortal.

Icon: A man hidden under a mortar to shoot arrows. (Fig.6)

Iconographic Analysis: Bow is a weapon consisting of an arrow to kill animals while the mortal is a hollowed tree (traditional) used in preparation of pounded yam. Symbolically, the mortar because of its physical nature (opaque) serves as a protector that covers the evil doers from being seen while executing his illicit acts project believing that no one ever sees him. 


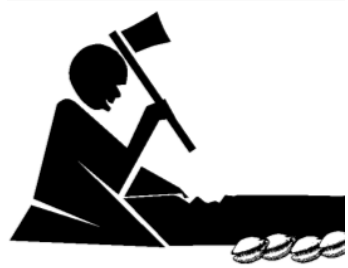

Fig. 5: Kìrà-kìtà kò mọ́là wá, ká șiṣẹ bí ẹrú kò dá nnkan kan fún ni

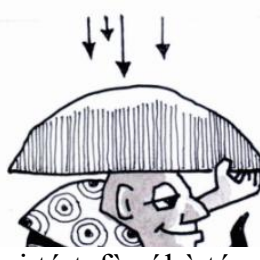

Fig. 6: Eni tó tafà sókè tó yídó borí , bí ọba ayé kò ri í, tọ̀run ń wò o.

7. Yoruba Proverbs: Kòkòrò tí ń jẹ ewe, ara ewé ló wà.

English Translation: The insects that eat up vegetables are always located within its premises.

Contextual meaning: This proverb is used when it is found either through physical or spiritual means that the enemy of a victim is inherently located within his/her premises. Every man lives with his problem. Though living together is good but how do we live together without stepping on each other's toe.

Socio-Cultural relevance: It is a common practice among the Yoruba people of Nigeria to consult sooth sayers, oracles, spiritualists or diviners to investigate the source of their problem. When such individuals are discovered it eventually turns out that they are been troubled with a relation (kith and kin). The proverb is now used to explain the dizzy situation.

Icon: Insect eating on a leaf (Fig.7)

Iconographic Analysis: The main idea in this proverb depicts the insect lying flat on the leaf which suggests closeness or oneness. However, the insect that lay on the leaf is not for good but for its selfishness and for the destruction of the leaf. Many people today conspire to kill or arm their best friends because of their inordinate ambition, envy or greed.

8. Yoruba Proverbs: Òrìsà jẹ ń pé méjì obìnrin, kò dénú.

English Translation: May the gods enlarge my family to allow my husband marry co-wives with me is a mere lip service. No woman will sincerely wish that.

Contextual meaning: The proverb depicts the self centeredness of human being using the considerable lip service of a second wife in a home. It is also used to despise satire anybody who claims to pray for the success of his colleagues sincerely while contending for the same position.

Socio-Cultural relevance: When there is a dispute between two parties in relation to their works, successes, marriage among others, the elders in Yoruba society always make it clear that human beings are selfish and that no one would wish his neighbor any good that will make the partner to outshine him/her.

Icon: Two silhouetted female figures

Iconographic Analysis: The idea of the proverbs is illustrated by two silhouetted figures that are backing each other. Though they are physically identical but they are spiritually not in the same thought. Humanly, it is deceitful for two women to agree to marry the same husband no matter the trust, comfort and satisfaction;

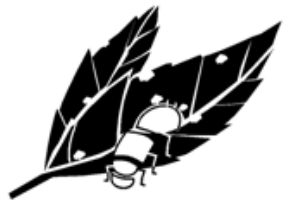

Fig. 7: Kìrà-kìtà kò mọ́là wá, ká șișẹ́ bí ệú kò dá nnkan kan fün ni

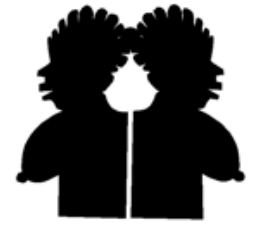

Fig. 8:Örìsà jẹe ń pé méjì obìnrin, kò dénú.

9. Yoruba Proverbs: Enu Enú dùn-ún-ròfọ́, agada owọ́ șé e bẹ gẹdú.

English Translation: It is easier said than done.

Contextual meaning: This is used to condemn empty boasting

easier said than done"

Socio-Cultural relevance: Making empty promises that are never fulfilled or raising lofty ideas without executing them is a social problem that is condemned by the Yoruba people in totality.

Icon: A man using hand to fell a tree. (Fig. 9) 
Iconographic Analysis: It is fallacious and unimaginable for a man to cut Iroko tree with mere hands. Likewise, it is a hyperbole to cook a tasty food without salt.

10. Yoruba Proverbs: Òrị̀à bí ífun kò sí, ojoojúmó ló ń gbẹbọ.

English Translation: There is no demanding deity like the stomach becuase its propitiation is on daily bases.

Contextual meaning: The proverb is advisory to condemn the insolents by highlighting the exigencies of food intake and underscores its daily demands that equally calls for provision of service. Making endless demands without corresponding results brings contempt and often it is discouraging.

Socio-Cultural relevance: A greed, glutton or bribe taker thinks about himself alone without considering the effects on others. People should learn to be moderate in whatever they do and should always consider the effect of what they do on the society at large. They shall not allow their inordinate ambition to becloud their reasoning as reflected in figure 10 below

Icons: A man with a basket of food. (Fig.10)

Iconographic Analysis: The main idea of this proverb is a man (glutton) with basket full of food. The idea is that a glutton is never satisfied even when the stomach is protruded. People should learn to be satisfied with what they get legally and not from proverbs bribery or through embezzlement of public funds. Eating without control may lead to constipation as corruption may lead to social decay.

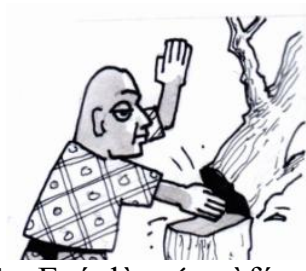

Fig. 9:EnuẸnú dùn -ún-ròfọ́, agada ọwọ́ șé e bẹ́ gẹdú

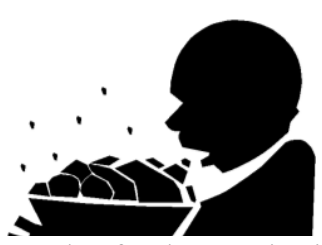

Fig. 10: Òrìșà bí ìfun kò sí, ojoojúmọ́ ló ń gbẹbọ

\section{Yoruba Proverbs: Asáré-tete kò ni kojá ilé. Arìn-gbẹrẹ kò ní sùn sọnà}

English Translation: A fast-moving pedestral would not go beyond his destination as a slow-moving one will not sleep on the way.

Contextual meaning: The proverb is used to instill the maxim of "slow and steady wins the race". There is time for everything because early marriage may not guarantee early child birth. This proverb suggests that people should work according to their strength, hence there will be problem. Everyone will get to his or her destination at Gods appointed time, so there is no need for unhealthy rivalry, a competition and rush with brute force..

Socio-Cultural relevance: Youth of today are restive. They want to ride big cars, live in mansion and get all the comforts of the world by resulting to diabolical means like consulting the oracles, sleeping in the grave yards or seeking the favour of diviners to make money rituals. The proverb is applied when the death of a youth is established to have a link with such.

Icons: Two men on a track; running and walking to get to their destinations.

Iconographic Analysis: The imageries in figure 11 depict two people heading for their homes. While one of them runs with his full energies to get home earlier without due consideration for any physical hazard or accidents, the other one chooses to walk gently and carefully to arrive home safely. Every being has a mission to accomplish on earth, however, this demand for caution. To run is to be over ambitious, greedy and desperate while walking translates to good vision, good organization, contentment and sincerity.

\section{Yoruba Proverbs: Àgbà kò sí ní ilú, ilú bàjẹ. Baálé ilé kú, ilé di ahoro}

English Translation: In the absence of an elder in the town, the town becomes disorganised. Following the demise of the elderly, the town becomes sacked.

Contextual meaning: It is used in to highlight the indispensability of the role of elders in any given set up. It underscores the untold calamities that usually take place in the absence of a good leader.

Socio-Cultural relevance: Many youths today have no respect for their indigenous culture simply because the elders/ parents slack in their primary role in the society.

Icon: A dilapidated building with the grave of the land-lord at the frontage. Iconographic Analysis: The idea of using a dilapidated house to represent this proverb suggests a situation where the house owner (landlord) dies without leaving behind any responsible members of his family to take charge at his demise. This makes the house to be dilapidated and the premises desolate. Again, a deplorable house in this context represents a society without order. It also represents a family, state, or nation with no operational laws, purposeful or visionary leader while the grave represents total decay in the society. 


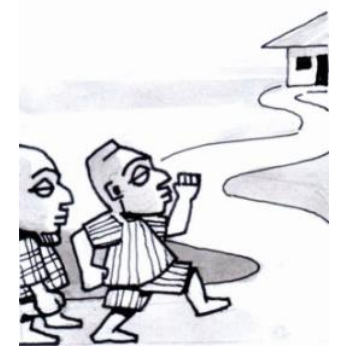

Fig. 11: Asáré-tete kò ni kọjá ilé. Arìn-gbẹ̀rẹ̀ kò ní sùn sọ́nà

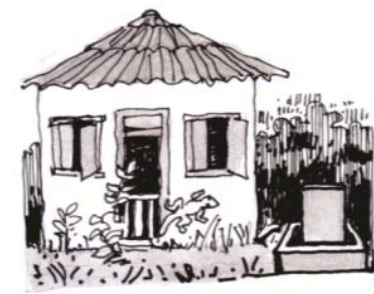

Fig. 12: Àgbà kò sí ní ìlú, ìú bàjẹe. Baálé ilé kú, ilé di ahoro

13. Yoruba Proverbs: Ẹlà lọ̀ọ̀, bí a kò bá là á, kì í yé ni.

English Translation: Isues deserve thorough explication without which they become puzzles and knotty Contextual meaning: The proverb is used when it is necessary to demand for further explanations for certain puzzles to enable the audience know the correct approach to such. Kola nut is an important seed used as refreshments and for rituals. They are better cut or split for easy chewing because it cannot be consumed wholly. It is so significant that their uses as item of prayers in the traditional society cannot be over emphasized. The knife cuts objects accurately and adequately, so also is a statement that contains proverbs.

Socio-Cultural relevance: Eating a cola nut seed is not due to its physical nature but becomes chewable and edible when it is shared or broken into consumable pieces.

Icon: Two pieces of kola nut with a knife cutting through one of them.

Iconographic Analysis: A piece of Kola nut and knife are keywords used as icon to depict the proverb in figure 13. The icon represents the traditionally role of kola nut as 1 a priceless fruit that is used to entertain or seal a deal in a critical life situation among the Yoruba people. Traditionally, nobody eats kola nut without cutting it into smaller units for easy consumption and for the purpose of sharing. Therefore, critical issues are supposed to be illuminating and explicable among the discussants to facilitate better understanding and full participation of.

14. Yoruba Proverbs: Bí a gúnyán si inú ewé, bí a șebẹ sinú èpò ẹpà, ẹni máa yó, a yó.

English Translation: However critical a situation may be, those that would survive it will still do.

Contextual meaning: The proverb is used as encouragement; when out of all unfortunate circumstances and upheavals, certain groups of people still come out successfully. This proverb counsels and makes us understand that it is neither by power nor might but by the special grace of our creator (elédá)

Socio-Cultural relevance: Being desperate in whatever we do or in whatever form may be counterproductive, fruitless and may not necessarily lead to any glorious achievement.

Icon: A ball of pounded yam on a leaf with soup in a groundnut shell.

Iconographic Analysis: A ball on a leaf that is standing beside a groundnut shell is the main idea from the proverb. The ball and the leaf represent pounded yam (a traditional Yoruba delicacy) while the groundnut shell contains the spice to consume the pounded yam. In a true life situation, it is extremely difficult to eat satisfactorily with the commensurate quantity of soup provided. However, in situations of dearth of spices some people will still eat satisfactorily with their belly protruded. In every life situation: wars, hunger, joblessness, inflation among others, some people still make it

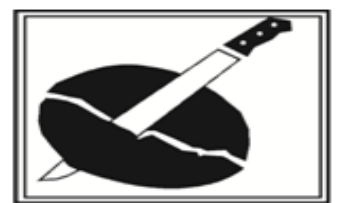

Fig. 13: Ėlàlò̀ò̀, bí a kòbálà á, kì î yéni

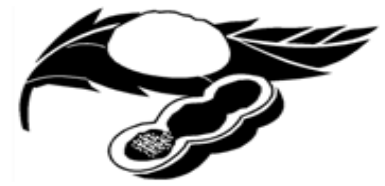

Fig. 14: Èlàlòrò, bí a kòbálà á, kì î yéni

15. Yoruba Proverbs: Igi gangangran má gún mi lójú, àti òkèèrè ni a ti i yẹe ẹ.

English Translation: Prevention is better than cure.

Contextual meaning: This proverb is often used as a warning about an impending danger that may arise from negligence, stubbornness, laziness or idleness. It is also used as a warning to the care-free to be cautious and clever against whatever is likely to cause trouble for them in future 
Socio-Cultural relevance: One should flee from whatever circumstances that can ruin one's life one should rise up to his challenges. Adequate and timely planning for one's life leads to success.

Icon: A long stick with several branches pointing at the eyes.

Iconographic Analysis: The long stick (arrow-like) with branches and the figure with eyes widely opened are the main idea from the proverb. There are so many arrow-like situations pointing into our eyes closed which demands for early prevention or total avoidance to afford liveliness and progress in life. The eye has no replacement; so also are time and lifetime opportunities. In essence we should run away from things that can destroy our future.

\section{Yoruba Proverbs: Ati òkèerè ni olójú jinjin ti í mú ẹkún sun. (Fig.16)}

English Translation: To be fore warned is to be fore armed.

Contextual meaning: The proverb warns that a stitch in time saves nine and, to be fore warned is to be fore armed.

Socio-Cultural relevance: Understanding one's ability is a veritable tool for individual growth and progress. Every individual is unique in a way' to that effect, the weak should know that he is weak; therefore should put in extra efforts to also succeed in life.

Icon; A man shedding tears.

Iconographic Analysis: The abstract male weeping figure is used to depict the popular saying. It will take a very long time for a man with very deep eye-socket to fill a bucket with tears coming out from his. To shed tears that will fill a bucket will require a long days of serious cry. Likewise, to succeed in life, one needs to be persistently determined, focused and tireless in whatever one chooses as a career. The icon connotes that one should plan early enough for a life time goal in order to achieve it. One should not wait or rescind to faith without adequate planning and conscientious efforts to one's ambition. The weeping figure represents determination, vigor, hopefulness and wisdom.

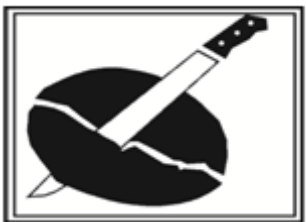

Fig. 13: Ė̀àlò̀ò̀, bí a kòbálà á, kì i yéni

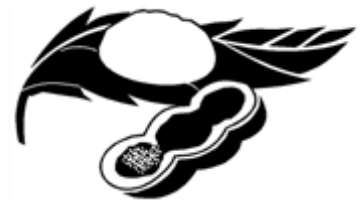

Fig. 14: Èlàlòtò̀, bí a kòbálà á, kì i yéni

\section{DISCUSSION}

From the analysis of the sixteen selected proverbs among the Yoruba people, it has been established that the use of Yoruba proverb is on its last leg, most especially now that the city dwellers are looking at anything cultural with utter disdain. However, the quest for globalization in the phase of linguistic alienation among the Youths, make it expedient for cultural renaissance to be embraced in order to enhance true Africaness and self actualization. But one other question arises: should we blame this treat of language extinction on the Youths alone? On the other hand, should we remind the elders of their apparent negligence which is corroborated by a Yoruba proverb which says "Bí onígbá bá ti șe pe igbá rè, ni à ń bá a pè é meaning that whatever name you give to your calabash (good/bad) is what the society will call it. The elders held their culture loosely because they also imbibe the spirit of modernism which is speedily sweeping away their cultural values. Perhaps, the older generations have forgotten that language is a strong sinew of culture, and the two are in inseparable relationship with each other.

The sixteen proverbs investigated in this study illuminated their various statuses, meanings and functions among the Yoruba people of southwestern Nigeria. The study provided better understanding of this cultural heritage. Likewise, a cursory look at the proverb in figure 1 expresses hopefulness while figures 2 and 10 express appreciation. Figure 3 serves as an instrument of counseling with figures 4, 7 and 11 uses as cautionary devices to caution people from embarking on a fruitless effort. The proverbs in figures 5, 6, 9, 15 and 16 aimed at warning people with great mind against inordinate ambition, greed and recklessness while figures 12 and 13 provides cultural, political or social education. Evidently, this study show that; proverbs are important tool that has been used to illuminate the society, invigorate the individuals.......it has also been used as a binding wire to sustain the norms and cultural values in most indigenous society like the Yoruba before the advent of colonization that affected their growth. More importantly, the philosophy contained in Yoruba proverbs as presented in this study makes it explicit to be used not only for art practices. And understanding but also as apparatus for pedagogy in arts class.. 


\section{CONCLUSION}

Conclusively, the field study revealed that many of the Yoruba youths have little or no understanding of Yoruba proverbs lest they use them in speech presentation at public gatherings. The study identified globalization, enforcement and compulsory use of English language as a medium of communication in schools, assimilation of foreign culture and beliefs in the speakers and user of English language as a symbol of elitism are grossly responsible for the fading of Yoruba language. Having investigated the sixteen randomly English translated Yoruba proverbs, the author posts that applying transformed iconographic imageries and their adoption to be used for art practices will enhance the teaching and learning outcomes of students in both the secondary and tertiary institutions in Nigeria.

\section{REFERENCES}

[1] Adegbite, W (1988), "Proverbs of Message Presentation in Simultaneous Translation From Yoruba into English" in Ife Studies in English (ISEL), 2(1)

[2] Aderinto, S.I. (2014), The Social Implications of Some Nigerian Yoruba and Ibo Proverbs onCarefulness: European Journal of English Language and Literature Studies, vol.2. No, 2, pp 49-55

[3] Adeyemi A. (2009). Rhetoric in Conflict-Related Yoruba Proverbs: Guide to Constructive Conflict Resolution in African. African Study Monographs, 30 (2): 55 - 69

[4] Adeyemi J. A. and Noah B. (2014). Proverbs and conflict Management in Africa: A study of Selected Yoruba Proverbs and Proverbial Expressions. International Journal of Literature, Language and Linguistics Vol, 1 (1), pp. 039 - 044.

[5] Agbaje, J.B, (2002), Proverbs: a strategy for resolving conflict in Yoruba society. Journal of frican Cultural Studies, Vol. 15, no 2

[6] Agbaje, J.B, (2005), The place of Yoruba Proverbs in The Understanding of Yoruba Philosophy and Education. International Journal of African and African American Studies, vol. 5

[7] Ajibade, G.O. (2006), "Inscription of Ethics of Labour and Productivity in Yoruba Proverbs" Proverbium, University of Vermont. Pp 31-48

[8] Asiyanbola A. A. (2007). A Syntactic and Semiotic Analysis of Some Yoruba Sexist Proverbs in English Translation: Need for Gender Balance.

[9] Babatunde A. A. and Mujidat O. S. (2014). The Place of Indigenous Proverbs in Peace Educationin Nigeria: Implications for Social Studies Curriculum. International Journal of Humanities and Social Science. Vol. 4 No. 2

[10] Bascom, W. (1969) The Yoruba People of Southwestern Nigeria. New York: Holt, Rinehart and Winston

[11] Bascom, W. (1989) A Yoruba Master Carver: Duga of Imeko. In Traditional Artist in African Society, (ed),Warren L.d'Azeredo.

[12] Diran A. B. (2012). The Aesthetics of 'Ladeoko Festival' of ISONA Ward in Ilesa, Nigeria:Journal of Humanistic Studies (Nos 21\&22).

[13] Fabunmi, F.A. etal(2005), "Is Yoruba an endangered Language?": Nodic Journal of AfricanStudies vol.14

[14] Fasiku Gbenga (2006), Yoruba Proverbs, Names and National Consciousness. Journal of Panrican Studies, vol.1, no.4,

[15] Fagg, W. etal (1982), The Yoruba Artist: Regional Styles and Descriptive Catalog". Yoruba Sculpture of West Africa. Ed. Bryce, Holcombe, New York.

[16] Graeme, B (2014) Conceptualisation in Visual Arts: An anthropological view, Magzeel press, Jahnor, Malaysia.

[17] Geoffrey, R. S. (2006) Transformation and Imaging: A tool for emerging Art Practices. JournalOf contemporary art studies, vol.3

[18] Makinde, D.O. (2014) Modernisation of Creative Culture: Ona in modern Nigeria Art, Unpublished Ph.D. Thesis, Department of Fine and Applied Arts, University of Nigeria, Nssuka.

[19] Mbagu, I (2010), Significance of proverbs in Africa and Beyond, http://afrostyle/mag.com /issue4/significance-of-proverbs-in-africa-an : Retrived on 15/08/20 15

[20] Kquofi, S. (2013) Symbolic Representation and Socio-Cultural Significance of Selected Akan Proverbs in Ghana, Research on Humanities and Social Sciences Vol. 3. No. 1,

[21] Kylie, F (2011), Art Practice in the $21^{\text {st }}$ Century Europe. Konga and Capel.

[22] Ogunwale, J.A. (2008) A Pragmalinguistic Study of Yoruba Proverbial Names. Journal of Onomastics University of Louisville.

[23] Ogunwale, J.A. (2012). A Pragmalinguistic Study of Yoruba Personal Names. Journal of Literary Onomastics Volume 2, Issue 1, Article 4. 
[24] Ojo, B. etal (2006), Yoruba Folktales: A Study of Childhood Experiences in Contemporary Printmaking, Australian Art Education, vol. 29, no. 1

[25] Paczolay, G (1977) European Proverbs in 55 languages, Veszpre'm Hungary

[26] Palmer, C. B (1999) Towards a study of cultural linguistics, Austin: University of Texas press.

[27] Panosky, E. (1984) Iconographic Images as Cultural; History; Journal of cultural and Anthropological studies, vol. 2

[28] Panosky, E. (1996), Humanistic Themes In art of the Renaissance.

[29] Salawudeen, A.S. (2014), Role of Yoruba Proverbs in socialization of the Youths, Implications for social studies curriculum. Paper presented at the $3^{\text {rd }}$ National conference of school of languages, Federal College of Education (Special) Oyo

[30] Thomas, R.F (1989) Yoruba Artistic Criticism in "Traditional Artist in African Society", (ed), WarrenL.d'Azeredo.

[31] Toni D. (2013). Animated Graphic Film for the Rejuvenation of a Fading African Culture: The case of an Igbo Heritage. International Academic Conference Proceedings (WEI) Orlando, USA.

[32] Yankah, K (2012) The proverb in the context of Akan Rhetoric, $2^{\text {nd }}$ revised edition, New YorkDiasporic Africa Press. 